\title{
Successful Remote Monitoring During COVID-19 Pandemic of Patients with Inborn Errors of the Amino acid Metabolism not including PKU from a Single Reference center using Filter Paper Samples
}

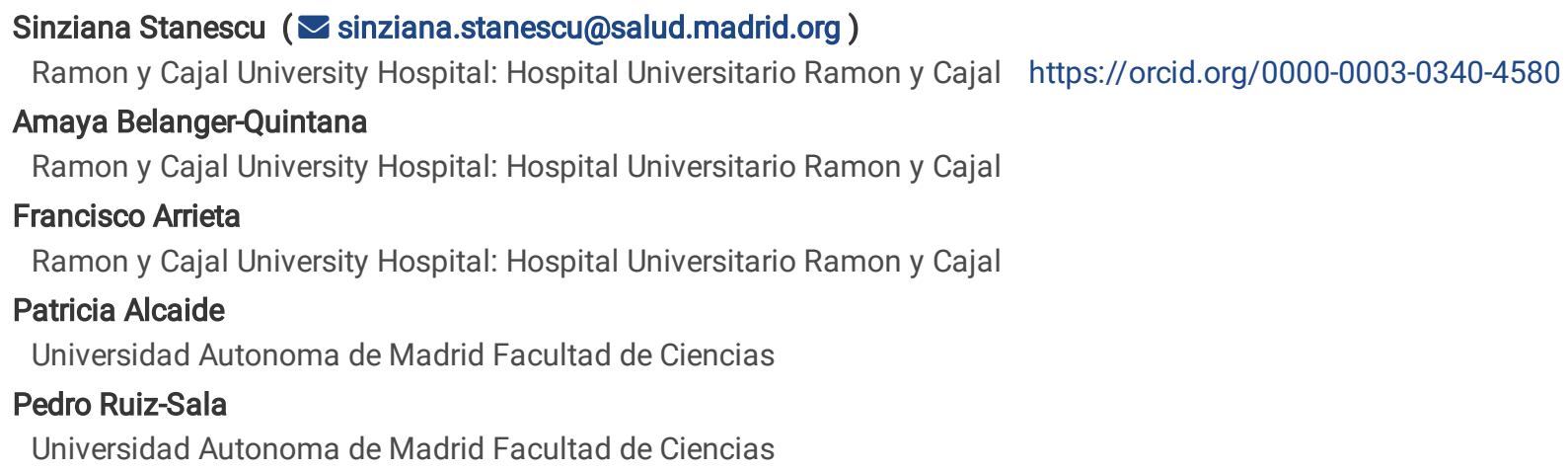

\section{Research}

Keywords: COVID-19, inborn errors of metabolism, monitoring, filter samples

Posted Date: December 10th, 2020

DOI: https://doi.org/10.21203/rs.3.rs-122663/v1

License: 두 (i) This work is licensed under a Creative Commons Attribution 4.0 International License. Read Full License 


\section{Abstract}

Background. Patients with inborn errors of metabolism (IEM) pose specific management challenges, considering their multisystem involvement. Among them, children and adults with organic acidemias (OA) and other disorders of the amino acid metabolism have a high risk for severe metabolic events that need to be recognized and promptly treated, and therefore require frequent clinical and biochemical evaluations. The novel highly pathogenic SARS-CoV2 virus appeared in Europe in the first trimester of 2020. This pandemic has a huge impact on the health care systems all over the world, interrupting the follow-up of many chronic diseases. For metabolic patients, travel to reference units may be reduced due to mobility restrictions but more importantly, attendance to medical facilities can be a risk of infection that can be a danger in itself but also trigger a metabolic decompensation.

Methods. During the first coronavirus disease (COVID-19) outbreak in Spain from March to June 2020, we designed a model of remote monitoring of our patients with amino acid disorders using telephone and/or online clinical assessments and using filter paper samples to continue the biochemical control.

Results. Fourteen patients with inborn errors of amino acid metabolism other than PKU received filter papers and instructions to collect blood and urine samples home and send them to our reference laboratory.

Conclusions. Considering the COVID19 pandemic evolution, new strategies to ensure IEM patients have an evaluation continuity need to be implemented. We believe that blood and urine filter paper biochemical follow-up, together with online or telephone clinical assessments, can help minimize the need for in-hospital visits.

\section{Introduction}

During the winter of 2019 a novel highly pathogenic coronavirus strain called SARS-CoV2 emerged in Wuhan, China, and rapidly spread all over the world, causing more than a million deaths so far (WHO Coronavirus Disease (COVID-19) Dashboard, 2020). The consequences of the SARS-CoV2 pandemic is not limited to the people infected by the virus. Fear of SaRS-CoV2 infection motivated by hospital clusters made both urgent and chronic patients avoid seeking medical attention (1) (2). Also, mobility restrictions and the collapse of the healthcare systems made live consultations and blood analysis extremely difficult.

People with preexisting medical conditions seem to be at higher risk for severe forms of COVID-19 (3). Among them, patients with inborn errors of metabolism (IEM) pose specific management challenges, considering the multisystem involvement of many of them. This is especially true for patients with pulmonary impairment or alterations of the immune system (splenectomy, primary immunodeficiencies or neutropenia) (4) (5) (6). Even if they are not at risk or do not develop severe forms of COVID-19, any infection can trigger a metabolic decompensation that has its own important morbi-mortality and that needs to be promptly recognized and treated.

Phenylketonuria (PKU) is the most common inborn error of amino acid metabolism. Other diseases frequently followed in metabolic centers include organic acidemias (OA), maple syrup urine disease (MSUD), glutaric aciduria (GA), tyrosinemia or homocystinuria, among others. Inborn errors of amino acid metabolism are genetic conditions with varying clinical presentations, but they share common general features. Many present clinically as a life-threatening episode consisting in severe metabolic acidosis, hyperammonemia, hypoglycemia or hepatic alterations; others might present with acute or chronic neurological involvement and some might have nonspecific clinical manifestations such as failure to thrive or recurrent vomiting, among others. Nowadays, most can be diagnosed by the neonatal screening. Treatment of these disorders is based in most cases in dietary management that includes a protein restrictive diet combined with a special amino acid mixture (SAAM) that contains all amino acids except those prior to the metabolic block. Supplementation might be necessary to avoid the deficiency of the amino acid that has become essential due to the enzymatic defect (7). Treatment might also include specific cofactors such as carnitine, glycine or different vitamins (8) (9) (10) (11). Dietary treatment avoids the accumulation of toxic metabolites and is generally effective in greatly improving the outcome (12), but even well controlled patients tend to develop different physical or neurological long-term complications. All inborn errors of amino acid metabolism share the need for frequent clinical and biochemical monitoring by a multidisciplinary trained team in order to adjust treatment. However, further acute metabolic crisis can be triggered by situations that induce protein catabolism such as intercurrent infections, immunization, surgery, prolonged fasting or certain medications such as the use of high doses of glucocorticoids (13). Depending on the disease, new crisis can be life-threatening, but in all patients frequent bad metabolic controls lead to increased long-term complications. Patients and their families should be trained to early recognize risk situations and implement treatment changes to avoid metabolic decompensations.

The metabolic unit of the Hospital Ramon y Cajal in Madrid, Spain, is a national reference center for both children and adults with inborn errors of metabolism. It is currently involved in the active follow-up of more than 700 patients with all kind metabolic diseases including amino acid, fatty acid or carbohydrate metabolism, lysosomal storage diseases or mitochondrial cytopathies. The hospital is a $3^{\text {rd }}$ level 
university facility for both children and adults with over 1500 beds and all recognized medical and surgical specialties. It houses not only ours but several other national reference centers for different pathologies.

Spain was one of the earliest and most affected countries during the first wave of COVID-19 that spread all over the world in the first half of 2020 (14). During this period, Madrid, in particular, had the highest rate of infections and hospitalizations in our country. The activity of our hospital during the months of March to May was completely shifted to attending COVID-19 patients. All but one of the physicians of the metabolic unit were transferred to the attention of COVID-19 patients.

We had to adapt our activity to the new conditions. In order to comply with government indications and to prevent the unnecessary exposure to the virus of our patients, live follow-up evaluations were suspended, and patients' consultations were mainly done by phone or via email. Biochemical follow-up became a challenge. Metabolic control using filter paper samples in phenylketonuria has been established for decades. In recent years, measurements of phenylalanine, tyrosine and succinylacetone in tyrosinemia patients has become a common practice. Based on the good results for diagnosis of the neonatal screening programs, and our previous reported experience in long term follow up of propionic acidemia using filter paper samples instead of the usual liquid plasma or urine samples (15), we designed a model of remote monitoring for all our amino acid disorder patients. We report the results of this program from March to June 2020 for these patients, excluding those with PKU in which this is the usual process.

\section{Materials And Methods}

All programmed visits for the patients were maintained with their usual frequency, depending on the age or needs of each patient, but they were done via phone or email. Additional calls were attended if necessary. Live consultations were reduced to a minimum but were maintained in very specific situations such as very young children or pregnancies. Emergency attention for adults was maintained and children consultations that could not be solved telematically were referred to one of the only two children's hospitals that were still operational in the city.

Patients were reminded of their emergency recommendations and received both oral and written instructions in case of coronavirus or other concurrent infections, personalized to their disease and situation, having in mind that many of our patients were from different regions of the country and therefore would have difficulties to reach our hospital if needed. The use of capillary glucose and/or ketone body detection was encouraged in those patients that had these devices available.

Filter papers were sent to the patients together with instructions on how to collect the blood and urine samples. Dried blood spot (DBS) and dried urine spot (DUS) were collected by the patient's family in their homes and sent to the laboratory by regular mail.

All laboratory measurements were completed in our ERNDIM approved, reference laboratory (CEDEM, Centro de Diagnostico de Enfermedades Moleculares, Universidad Autonoma, Madrid). Acylcarnitines and amino acids in DBS were determined as their butyl esters by flow injection analysis-tandem mass spectrometry with stable isotope dilution (16) (17). Simultaneously, acylcarnitines were acquired by precursor ion scan of $\mathrm{m} / \mathrm{z} 85$ mode and amino acids by neutral loss of 102 amu, except basic amino acids, glycine, leucine and isoleucine which were acquired by MRM (multiple reaction monitoring). Organic acids and acylglycines in DUS were analyzed by HPLC-tandem mass spectrometry and MRM mode (16). In addition, an ACE C18 HPLC column was included to resolve MRM isomers (18). Succinylacetone in DBS was analysed by tandem mass spectrometry in MRM mode with stable isotope dilution $\left({ }^{13} \mathrm{C}_{5}\right.$-succinylacetone) after butylation.

\section{Results}

During this period, 14 patients aged 1 to 24 years with different amino acid inborn errors of metabolism other than PKU required monitoring by our metabolic unit: 4 patients with propionic acidemia (PA), 2 patients with $c b / C$ type methylmalonic acidemia (cb/C type MMA+Hcty), 2 patients with isovaleric acidemia (IVA), 2 patients with maple syrup urine disease (MSUD), 1 patient with glutaric aciduria type I, 1 patient with glutaric aciduria type III, 1 patient with hereditary tyrosinemia type I (HT type 1) and 1 patient with classic homocystinuria. Other patients had had recent live consultations and/or biochemical analysis was not deemed necessary during this period. The demographic and clinical characteristics of these patients are presented in Table 1. 
Table 1

Clinical and demographic characteristics of the patients.

\begin{tabular}{|c|c|c|c|c|c|c|c|}
\hline \multirow[b]{2}{*}{ Diagnosis } & \multirow[b]{2}{*}{ Age } & \multirow[b]{2}{*}{ Age at diagnosis } & \multirow[b]{2}{*}{$\begin{array}{l}\text { Chronic } \\
\text { complications }\end{array}$} & \multirow[b]{2}{*}{$\begin{array}{l}\text { Current } \\
\text { treatment }\end{array}$} & \multicolumn{3}{|c|}{ March-June 2020 (COVID-19 lockdown) } \\
\hline & & & & & $\begin{array}{l}\text { Follow up } \\
\text { samples }\end{array}$ & Complications & $\begin{array}{l}\text { Treatment } \\
\text { changes }\end{array}$ \\
\hline \multirow[t]{5}{*}{$\begin{array}{l}\text { 1. Propionic } \\
\text { acidemia }\end{array}$} & \multirow[t]{5}{*}{$14 y$} & \multirow[t]{5}{*}{$\begin{array}{l}\text { Neonatal } \\
\text { (hyperammonemia) }\end{array}$} & \multirow[t]{5}{*}{$\begin{array}{l}\text { Recurrent } \\
\text { pancreatitis }\end{array}$} & $\begin{array}{l}\text { NP: } 0.5 \\
\text { g/kg/day }\end{array}$ & Regular control & \multirow[t]{5}{*}{ None } & \multirow[t]{5}{*}{ None } \\
\hline & & & & SAAM: 1.7 & \multirow{3}{*}{$\begin{array}{l}\text { DBS } \\
\text { (acylcarnitines, } \\
\text { amino acids) }\end{array}$} & & \\
\hline & & & & g/kg/day & & & \\
\hline & & & & Carnitine & & & \\
\hline & & & & $\begin{array}{l}\text { lle } \\
\text { supplements }\end{array}$ & $\begin{array}{l}\text { DUS (organic } \\
\text { acids) }\end{array}$ & & \\
\hline \multirow[t]{5}{*}{$\begin{array}{l}\text { 2. Propionic } \\
\text { acidemia }\end{array}$} & \multirow[t]{5}{*}{$8 y$} & \multirow[t]{5}{*}{$\begin{array}{l}\text { Neonatal } \\
\text { (screening) }\end{array}$} & \multirow[t]{5}{*}{ Autism } & $\begin{array}{l}\text { NP: } 1 \\
\text { g/kg/day }\end{array}$ & Regular control & \multirow[t]{5}{*}{ None } & \multirow[t]{5}{*}{ None } \\
\hline & & & & SAAM: 2 & I sampre & & \\
\hline & & & & g/kg/day & $\begin{array}{l}\text { DBS } \\
\text { (acylcarnitines, }\end{array}$ & & \\
\hline & & & & Carnitine & amino acids) & & \\
\hline & & & & $\begin{array}{l}\text { lle } \\
\text { supplements }\end{array}$ & $\begin{array}{l}\text { DUS (organic } \\
\text { acids) }\end{array}$ & & \\
\hline \multirow[t]{4}{*}{$\begin{array}{l}\text { 3. Propionic } \\
\text { acidemia }\end{array}$} & \multirow[t]{4}{*}{$12 y$} & \multirow[t]{4}{*}{$\begin{array}{l}3 \text { months } \\
\text { (hyperammonemia) }\end{array}$} & \multirow{4}{*}{$\begin{array}{l}\text { Severe } \\
\text { neuromotor } \\
\text { delay }\end{array}$} & $\begin{array}{l}\text { NP: } 0.6 \\
\text { g/kg/day }\end{array}$ & Regular control & \multirow[t]{4}{*}{ None } & \multirow[t]{4}{*}{ None } \\
\hline & & & & $\begin{array}{l}\text { SAAM: } 2 \\
\text { g/kg/day }\end{array}$ & $\begin{array}{l}\text { DBS } \\
\text { (acylcarnitines, }\end{array}$ & & \\
\hline & & & & Carnitine & amino acids) & & \\
\hline & & & & $\begin{array}{l}\text { Ile } \\
\text { supplements }\end{array}$ & $\begin{array}{l}\text { DUS (organic } \\
\text { acids) }\end{array}$ & & \\
\hline \multirow[t]{4}{*}{$\begin{array}{l}\text { 4. Propionic } \\
\text { acidemia }\end{array}$} & \multirow[t]{4}{*}{$10 y$} & \multirow[t]{4}{*}{$\begin{array}{l}\text { Neonatal } \\
\text { (hyperammonemia) }\end{array}$} & $\begin{array}{l}\text { Severe } \\
\text { neuromotor } \\
\text { delay }\end{array}$ & $\begin{array}{l}\text { NP: } 0.6 \\
\text { g/kg/day }\end{array}$ & $\begin{array}{l}\text { Regular control } \\
1 \text { sample }\end{array}$ & $\begin{array}{l}\text { Acrodermatitis } \\
\text { (diaper rash) }\end{array}$ & $\begin{array}{l}\text { Initiation of } \\
\text { Val } \\
\text { supplements }\end{array}$ \\
\hline & & & Anemia & g/kg/day & DBS & & \\
\hline & & & trecatiosema & Carnitine & amino acids) & & \\
\hline & & & & $\begin{array}{l}\text { lle } \\
\text { supplements }\end{array}$ & $\begin{array}{l}\text { DUS (organic } \\
\text { acids) }\end{array}$ & & \\
\hline $\begin{array}{l}\text { 5. Isovaleric } \\
\text { acidemia }\end{array}$ & $15 y$ & & None & $\begin{array}{l}\text { NP: } 1 \\
\text { g/kg/day }\end{array}$ & & None & None \\
\hline & & (affected sibling) & & Carnitine & 1 sample & & \\
\hline & & & & Glycine & $\begin{array}{l}\text { DBS } \\
\text { (acylcarnitines, } \\
\text { amino acids) }\end{array}$ & & \\
\hline & & & & & $\begin{array}{l}\text { DUS (organic } \\
\text { acids) }\end{array}$ & & \\
\hline $\begin{array}{l}\text { 6. Isovaleric } \\
\text { acidemia }\end{array}$ & $24 y$ & & None & $\begin{array}{l}\text { NP: } 1.5 \\
\text { g/kg/day }\end{array}$ & & None & None \\
\hline & & (recurrent vomiting) & & Carnitine & 1 sample & & \\
\hline & & & & Glycine & $\begin{array}{l}\text { DBS } \\
\text { (acylcarnitines, } \\
\text { amino acids) }\end{array}$ & & \\
\hline & & & & & $\begin{array}{l}\text { DUS (organic } \\
\text { acids) }\end{array}$ & & \\
\hline $\begin{array}{l}\text { 7. Glutaric } \\
\text { aciduria type I }\end{array}$ & $18 y$ & 1 years & $\begin{array}{l}\text { Severe } \\
\text { neuromotor }\end{array}$ & $\begin{array}{l}\text { NP: } 1.5 \\
\text { g/kg/day }\end{array}$ & Regular control & None & None \\
\hline & & (dystonia) & delay & Carnitine & 1 sample & & \\
\hline & & & Dystonia & & $\begin{array}{l}\text { DBS } \\
\text { (acylcarnitines, }\end{array}$ & & \\
\hline
\end{tabular}


amino acids)

\begin{tabular}{|c|c|c|c|c|c|c|c|}
\hline $\begin{array}{l}\text { 8. Glutaric } \\
\text { aciduria type III }\end{array}$ & $16 y$ & $\begin{array}{l}\text { Neonatal } \\
\text { (hyperammonemia) }\end{array}$ & None & $\begin{array}{l}\text { NP: } 1 \\
\text { g/kg/day } \\
\text { SAAM } 1 \\
\text { g/kg/day } \\
\text { Carnitine }\end{array}$ & $\begin{array}{l}\text { Regular control } \\
1 \text { sample } \\
\text { DBS } \\
\text { (acylcarnitines, } \\
\text { amino acids) } \\
\text { DUS (organic } \\
\text { acids) }\end{array}$ & None & None \\
\hline $\begin{array}{l}\text { 9. Cobalamin } \\
\text { deficiency type } \\
\text { cb/C(MMA + } \\
\text { Hcty) }\end{array}$ & $7 y$ & $\begin{array}{l}\text { Neonatal } \\
\text { (hyperammonemia) }\end{array}$ & $\begin{array}{l}\text { Severe } \\
\text { neuromotor } \\
\text { delay } \\
\text { Epilepsy } \\
\text { Cardiomyopathy }\end{array}$ & $\begin{array}{l}\text { NP: } 2 \\
\text { g/kg/day } \\
\text { Vitamine } \\
\text { B12 } \\
\text { Carnitine } \\
\text { Betaine }\end{array}$ & $\begin{array}{l}\text { Febrile episode } \\
\text { and control } \\
2 \text { samples } \\
\text { DBS } \\
\text { (acylcarnitines, } \\
\text { amino acids) } \\
\text { DUS (organic } \\
\text { acids) }\end{array}$ & $\begin{array}{l}\text { Lactic } \\
\text { aciduria } \\
\text { No clinical } \\
\text { changes }\end{array}$ & $\begin{array}{l}\text { Stop of } \\
\text { protein } \\
\text { intake and } \\
\text { rise of } \\
\text { caloric } \\
\text { intake } \\
\text { during } 48 \\
\text { hours }\end{array}$ \\
\hline $\begin{array}{l}\text { 10. Cobalamin } \\
\text { deficiency type } \\
\text { cb/C (MMA + } \\
\text { Hcty) }\end{array}$ & $9 y$ & $\begin{array}{l}\text { Neonatal } \\
\text { (encephalopathy, } \\
\text { rash and } \\
\text { cardiomyopathy) }\end{array}$ & $\begin{array}{l}\text { Maculopathy } \\
\text { Cardiomyopathy } \\
\text { ADHD }\end{array}$ & $\begin{array}{l}\text { NP: } 1 \\
\text { g/kg/day } \\
\text { SAAM: } 1 \\
\text { g/kg/day } \\
\text { Vitamine } \\
\text { B12 } \\
\text { Carnitine } \\
\text { Betaine }\end{array}$ & $\begin{array}{l}\text { Regular control } \\
1 \text { sample } \\
\text { DBS } \\
\text { (acylcarnitines, } \\
\text { amino acids) } \\
\text { DUS (organic } \\
\text { acids) }\end{array}$ & None & None \\
\hline $\begin{array}{l}\text { 11. Maple } \\
\text { syrup urine } \\
\text { disease }\end{array}$ & $1 y$ & $\begin{array}{l}\text { Neonatal } \\
\text { (screening) }\end{array}$ & None & $\begin{array}{l}\text { NP: } 1 \\
\text { g/kg/day } \\
\text { SAAM: } 1 \\
\text { g/kg/day } \\
\text { Thiamine }\end{array}$ & $\begin{array}{l}\text { Regular control } \\
1 \text { sample } \\
\text { DBS } \\
\text { (acylcarnitines, } \\
\text { amino acids) }\end{array}$ & None & None \\
\hline $\begin{array}{l}\text { 12. Maple } \\
\text { syrup urine } \\
\text { disease }\end{array}$ & $8 y$ & $\begin{array}{l}\text { Neonatal } \\
\text { (screening) }\end{array}$ & None & $\begin{array}{l}\text { NP: } 0.7 \\
\text { g/kg/day } \\
\text { SAAM: } 1.7 \\
\text { g/kg/day } \\
\text { Thiamine }\end{array}$ & $\begin{array}{l}\text { Regular control } \\
1 \text { sample } \\
\text { DBS } \\
\text { (acylcarnitines, } \\
\text { amino acids) }\end{array}$ & None & None \\
\hline $\begin{array}{l}13 . \\
\text { Tyrosinemia } \\
\text { type I }\end{array}$ & $8 y$ & $\begin{array}{l}\text { Neonatal } \\
\text { (screening) }\end{array}$ & $\begin{array}{l}\text { ADHD } \\
\text { Speech delay }\end{array}$ & $\begin{array}{l}\text { NP: 0.8-1 } \\
\text { g/kg/day } \\
\text { SAAM: 1-1.5 } \\
\text { g/kg/day }\end{array}$ & $\begin{array}{l}\text { Regular control } \\
1 \text { sample } \\
\text { DBS } \\
\text { (succinilacetone, } \\
\text { amino acids) }\end{array}$ & None & None \\
\hline $\begin{array}{l}14 . \\
\text { Homocystinuria }\end{array}$ & $3 y$ & $\begin{array}{l}\text { Neonatal } \\
\text { (screening) }\end{array}$ & None & $\begin{array}{l}\text { NP: } 1 \\
\text { g/kg/day } \\
\text { SAAM: } 1.5 \\
\text { g/kg/day } \\
\text { Vitamine } \\
\text { B12 } \\
\text { Folinic acid } \\
\text { Betaine }\end{array}$ & $\begin{array}{l}\text { Regular control } \\
1 \text { sample } \\
\text { DBS (amino } \\
\text { acids) }\end{array}$ & None & None \\
\hline
\end{tabular}

DBS: dried blood spots; DUS: dried urine spot; SAAM: special amino acid mixture; NP: natural protein; ADHD: attention deficit/ hyperactivity disorder; lle: isoleucine; Val: Valine; MMA+Hcty: methylmalonic acidemia with homocystinuria

During the follow up we continuedly assessed patients by phone or email so the patients received the same number of virtual visits as usual (1 medical visit each 3-6 months if no emergency situations arise). No patient needed hospital admission for severe metabolic crises. One of 
the patients with cobalamin metabolism type $\mathrm{C}$ deficiency had a concurrent mild non-SARS-CoV2 respiratory infection and her parents began the emergency regimen at home with full control of symptoms in 48 hours. The DBS/DUS sample taken at the time detected a mild metabolic decompensation (lactic aciduria of $543 \mathrm{mmol} / \mathrm{mol}$ creat (VN: 61 \pm 41$)$ ) but no further measures were necessary and the biochemical control a few days later was normal. Another male PA patient called and sent pictures because of diaper rash. He already was on isoleucine supplements, so, based on the very low DBS valine levels $(26 \mu \mathrm{mol} / \mathrm{L}(\mathrm{VN}: 102 \pm 23))$, we decided to supplement with this amino acid. There was an important clinical improvement in a few days and the metabolic control done a few months later was adequate. None of the other patient had any significant change in their clinical or metabolic status, so they did not require any treatment modifications during this period other than small adjustments done due to weight gain.

\section{Discussion}

Many aspects interfere with IEM care during the COVID-19 pandemic. Newborn screening programs (NBS) had to be adapted in many countries. In some cases, early discharge from maternity wards required sending nurses to the homes of newborn children to collect the samples; in other countries such as China, consensus recommends that neonates whose mothers are suspected or diagnosed of COVID-19 would not be performed routine NBS, and testing should be delayed until their mothers were released from a 14-day quarantine and had two negative results of 2019-nCoV's RNA testing (19).

Regarding the long-term follow-up of IEM patients, a global survey study of the health service provided to these patients between March 1 st and May $31^{\text {st }} 2020$ concluded that the specific IEM units activity decreased between $60-80 \%$ comparing with the same period of 2019 (20). In some cases, this reduction is derived from the patients, due to fear of infection if going to medical facilities and/or the difficulty to reach the metabolic center due to mobility restrictions or fear of using collective means of transportation. Also, live attention was suspended in many hospitals and even some centers, such as ours, had severe staff reductions as many of their members were asked to attend other COVID-19 related activities.

Metabolic units around the globe have tried to adapt the patients' follow up to the new conditions. Most have amplified or implemented phone, email or other platforms of communication in order to maintain the contact with the patients and their families (21). In patients with lysosomal storage diseases, home infusion or higher doses were suggested in order to adapt the treatment (22). However, biochemical control of patients requires in many cases blood extractions and urine samples that need to be collected in a medical facility, and this kind of attention could not be performed in many centers during the worst weeks of the coronavirus pandemic.

The use of filter paper samples for the follow-up of phenylketonuria (PKU) patients is well established and therefore not included in this paper. For other amino acid disorders the use of this method for their detection in NBS is already standardized (23), but there was no validation of the long-term use of this kind of samples. Other authors have validated the filter sample method of monitoring patients with hereditary tyrosinemia type I (24). We recently published our experience in long term follow up of propionic acidemia with DBS and DUS (15). Both papers highlight that DUS and DBS correctly reflect the metabolic status in propionic acidemia and type I tyrosinemia respectively, allowing to adjust the treatment and facilitate the metabolic control.

During the first COVID-19 wave in Spain from March to June 2020, we maintained communication with all our metabolic patients via phone or email. Attention of some patients that could only be evaluated through live visits was either done under strict measures or postponed, but for most patients with amino acid disorders the use of filter paper samples and remote clinical evaluation allowed us to maintain their regular schedule and had the same number of visits as in 2019. None of these patients experienced a major metabolic event and the previous education, together with the telephone communication and filter paper samples allowed us to adequately manage the mild decompensation of the patient with cobalamin metabolism type $\mathrm{C}$ deficiency. In the patient with propionic acidemia with skin abnormalities in the diaper area, low valine levels could be observed and treated with good clinical and biochemical results. Acrodermatitis enteropathica-like skin lesions have been previously described in maple syrup urine disease patients and less frequently in propionic and methylmalonic acidemia, associated with low levels of isoleucine and valine (9) (25) (26) (27) (28). To avoid them, treatment guidelines for these diseases suggest single amino acid supplementation (7) (8).

It is obvious that remote monitoring in IEM cannot fully ensure the proper continuity and the high-level care that these patients need. Remote clinical assessments in children many times are done with parents but might exclude the patient. Physical examination, a pillar of the medical evaluation, is lacking. Due to staff shortage and because of the nature of this kind of communication patients were not evaluated by the complex multidisciplinary team that is usually standard. Even the biochemical control was incomplete, as filter papers could be used to measure amino acids and acylcarnitines but cannot be used for the full nutritional evaluation that has to be performed regularly.

On the other hand, remote clinical assessments and filter paper samples did provide a good method to maintain communication with patients during the time of the COVID-19 outbreak and allowed us to detect biochemical changes that could be managed by the patients at 
home without having to use other medical facilities. Taking into consideration the evolution of this pandemic, it will be necessary to maintain this kind of attention in the future. Even outside of this situation, using remote attention of patients will probably become more common as it reduces time and travel inconveniences for the patient and their families. This kind of extraction is also easier and more convenient, even in an in-clinic setting.

\section{Conclusions}

New strategies to ensure IEM patients continuity need to be implemented, considering the COVID-19 pandemic evolution. Remote clinical assessments are now indispensable and probably will become part of the regular schedule in the future, minimizing in-hospital visits and increasing the patients' autonomy. Filter paper samples have been shown to be useful not only in the diagnosis but also the long-term followup of many amino acid disorders. The simplicity of extraction and transportation of these samples have considerable advantages.

\section{Declarations}

\section{Ethics approval and consent to participate:}

This article does not contain any studies with human or animal subjects performed by any of the authors. The patients signed a consent statement previous to the inclusion in the study. The study was approved by the Ethical Committee of our hospital (Hospital Universitario Ramon y Cajal, Madrid, Spain).

\section{Consent for publication:}

not applicable.

\section{Availability of data and materials:}

The data and materials are available upon request

\section{Potential competing interests}

SS has received travel and speaker fees from Nutricia, Mead Johnson, Genzyme, Recordatti Rare Diseases, Vitaflo-Nestlé, BioMarin.

ABQ has received travel and speaker fees from Nutricia, Mead Johnson, Genzyme, Recordatti Rare Diseases, Vitaflo-Nestlé, Takeda, BioMarin; advisory fees from BioMarin and Merk Serono.

FA has received travel and speaker fees from Nutricia, Mead Johnson, Recordatti Rare Diseases, Vitaflo-Nestlé, BioMarin.

PA declares that she has no conflict of interest.

PRS declares that he has no conflict of interest.

\section{Funding:}

no funding was received for the present study.

\section{Authors' contributions:}

SS and $A B Q$ had a significant contribution to the conception and design of the study. All authors have contributed to the acquisition and the interpretation of the data and gave the final approval for the article.

\section{Acknowledgements:}

Dr Mercedes Martinez-Pardo MD, PhD contributed to the implementation of the long-term monitoring with filter paper samples in patients with Propionic Acidemia. 


\section{References}

1. Toniolo M, Negri F, Antonutti M, Masè M, Facchin D. Unpredictable Fall of Severe Emergent Cardiovascular Diseases Hospital Admissions During the COVID-19 Pandemic: Experience of a Single Large Center in Northern Italy. J Am Heart Assoc. 2020. doi:10.1161/JAHA.120.017122.

2. Lazzerini M, Barbi E, Apicella A, Marchetti F, Cardinale F, Trobia G. Delayed access or provision of care in Italy resulting from fear of COVID-19. Lancet Child Adolesc Health. 2020. doi:10.1016/S2352-4642(20)30108-5.

3. Zhou F, Yu T, Du R, Fan G, Liu Y, Liu Z, Xiang J, Wang Y, Song B, Gu X, Guan L, Wei Y, Li H, Wu X, Xu J, Tu S, Zhang Y, Chen H, Cao B. Clinical course and risk factors for mortality of adult inpatients with COVID-19 in Wuhan, China: a retrospective cohort study. Lancet. 2020;395:1054-62.

4. Andrade-Campos M, Escuder-Azuara B, de Frutos LL, Serrano-Gonzalo I, Giraldo P, GEEDL; FEETEG; AEEFEG. Direct and indirect effects of the SARS-CoV-2 pandemic on Gaucher Disease patients in Spain: Time to reconsider home-based therapies? Blood Cells Mol Dis. 2020. doi:10.1016/j.bcmd.2020.102478.

5. Mercolini F, Donà D, Girtler Y, Mussner KA, Biban P, Bordugo A, Molinaro G. First paediatric COVID-19 associated death in Italy. J Paediatr Child Health. 2020. doi:10.1111/jpc.14994.

6. Parvaneh N, Quartier P, Rostami P, Casanova JL, de Lonlay P. Inborn errors of metabolism underlying primary immunodeficiencies. J Clin Immunol. 2014;34:753-71.

7. van Vliet D, Derks TG, van Rijn M, de Groot MJ, MacDonald A, Heiner-Fokkema MR, van Spronsen FJ. Single amino acid supplementation in aminoacidopathies: a systematic review. Orphanet J Rare Dis. 2014;13:9:7.

8. Baumgartner MR, Hörster F, Dionisi-Vici C, Haliloglu G, Karall D, Chapman KA, Huemer M, Hochuli M, Assoun M, Ballhausen D, Burlina A, Fowler B, Grünert SC, Grünewald S, Honzik T, Merinero B, Pérez-Cerdá C, Scholl-Bürgi S, Skovby F, Wijburg F, MacDonald A, Martinelli D, Sass JO, Valayannopoulos V, Chakrapani A. Proposed guidelines for the diagnosis and management of methylmalonic and propionic acidemia. Orphanet J Rare Dis. 2014;2:9:130.

9. Frazier DM, Allgeier C, Homer C, Marriage BJ, Ogata B, Rohr F, Splett PL, Stembridge A, Singh RH. Nutrition management guideline for maple syrup urine disease: An evidence- and consensus-based approach. Mol Genet Metab. 2014;112:210-4.

10. Boy N, Mühlhausen C, Maier EM, Heringer J, Assmann B, Burgard P, Dixon M, Fleissner S, Greenberg CR, Harting I, Hoffmann GF, Karall D, Koeller DM, Krawinkel MB, Okun JG, Opladen T, Posset R, Sahm K, Zschocke J, Kölker S. Proposed recommendations for diagnosing and managing individuals with glutaric aciduria type I: second revision. $J$ Inherit Metab Dis 2017, 40;75-101.

11. Vockley J, Ensenauer R. Isovaleric acidemia: new aspects of genetic and phenotypic heterogeneity. Am J Med Genet C Semin Med Genet. 2006;15:95-103.

12. Saudubray JM, Sedel F, Walter JH. Clinical approach to treatable inborn metabolic diseases: an introduction. J Inherit Metab Dis. 2006;29:261-74.

13. Ogier de Baulny H, Dionisio-Vici C, Wendel U. Branched-chain organic acidurias/ acidaemias. In Saudubray JM, van den Berghe G, Walter JH, editors. Inborn Metabolic Diseases, 5th Edition Heidelberg: Springer; 2012. p. 278 - 96.

14. The Lancet Public Health. COVID-19 in Spain: a predictable storm? Lancet Public Health. 2020. doi:10.1016/S2468-2667(20)30239-5.

15. Stanescu S, Belanger-Quintana A, Fernandez-Felix BM, Perez-CerdaC, Merinero B, Ruiz-Sala P, Martinez-Pardo M. (2020). Long-term follow-up with filter paper samples in patients with propionic acidemia. JIMD Reports 2020; doi.org/10.1002/jmd2.12166. Epub ahead of print.

16. Ferrer I, Ruiz-Sala P, Vicente Y, Merinero B, Pérez-Cerdá C, Ugarte M. Separation and identification of plasma short-chain acylcarnitine isomers by HPLC/MS/MS for the differential diagnosis of fatty acid oxidation defects and organic acidemias. J Chromatogr B Analyt Technol Biomed Life Sci. 2007;860:121-6.

17. Casetta B, Tagliacozzi D, Shushan B, Federici G. Development of a method for rapid quantitation of amino acids by liquid chromatography-tandem mass spectrometry (LC-MSMS) in plasma. Clin Chem Lab Med. 2000;38:391-401.

18. Rebollido-Fernandez MM, Castiñeiras DE, Bóveda MD, Couce ML, Cocho JA, Fraga JM. Development of electrospray ionization tandem mass spectrometry methods for the study of a high number of urine markers of inborn errors of metabolism. Rapid Commun Mass Spectrom. 2012;26:2131-44.

19. Liu S, Wang D, Wan K, Liu H, Zhang D, Yang J, Yuan Z, He X, Wang J, Ou M, Zhu W, Qu Y, Zhao D, Wang W, Liu S, Gu M, Huang S, Wang Z, Zou L. Chinese expert brief consensus on newborn screening of inherited metabolic disorders during the novel coronavirus infection epidemic. Ann Transl Med. 2020. doi:10.21037/atm.2020.03.60.

20. Elmonem MA, Belanger-Quintana A, Bordugo A, Boruah R, Cortès-Saladelafont E, Endrakanti M, Giraldo P, Grünert SC, Gupta N, Kabra M, Knerr I, Krämer J, Kuster A, Levtchenko E, Ngu LH, Rovira-Remisa MM, Sass JO, Sykut-Cegielska J, Tummolo A, van den Heuvel LP. The

Page 8/9 
impact of COVID-19 pandemic on the diagnosis and management of inborn errors of metabolism: A global perspective. Mol Genet Metab. 2020. doi:10.1016/j.ymgme.2020.09.004. Epub ahead of print.

21. Brunetti-Pierri N, Fecarotta S, Staiano A, Strisciuglio P, Parenti G. Ensuring continuity of care for children with inherited metabolic diseases at the time of COVID-19: the experience of a metabolic unit in Italy. Genet Med. 2020;22:1178-80.

22. Mistry P, Balwani M, Barbouth D, Burrow TA, Ginns El, Goker-Alpan O, Grabowski GA, Kartha RV, Kishnani PS, Lau H, Lee CU, Lopez G, Maegawa G, Packman S, Prada C, Rosenbloom B, Lal TR, Schiffmann R, Weinreb N, Sidransky E. Gaucher disease and SARS-CoV-2 infection: Emerging management challenges. Mol Genet Metab. 2020;130:164-9.

23. Almannai M, Marom R, Sutton VR. Newborn screening: a review of history, recent advancements, and future perspectives in the era of next generation sequencing. Curr Opin Pediatr. 2016;28:694-9.

24. Schultz MJ, Netzel BC, Singh RH, Pino GB, Gavrilov DK, Oglesbee D, Raymond KM, Rinaldo P, Tortorelli S, Smith WE, Matern D. Laboratory monitoring of patients with hereditary tyrosinemia type I. Mol Genet Metab. 2020;130:247-54.

25. Bodemer C, De Prost Y, Bachollet B, Poggi F, Teillac-Hamel D, Fraitag S, Saudubray JM. Cutaneous manifestations of methylmalonic and propionic acidaemia: a description based on 38 cases. Cutaneous manifestations of methylmalonic and propionic acidaemia: a description based on 38 cases. Br J Dermatol. 1994;131:93-8.

26. Bosch AM, Sillevis Smitt JH, Van Gennip AH, Abeling NG, Schutgens RB, Bakker HD, Wijburg FA. latrogenic isolated isoleucine deficiency as the cause of an acrodermatitis enteropathica-like syndrome. Br J Dermatol. 1998;139:488-91.

27. Vitoria Miñana I, Dalmau Serra J. Enteropathic acrodermatitis-like lesions in valine deficiency methylmalonic acidaemia. An Pediatr (Barc). 2010;72:96-7. Spanish.

28. Blecker U, De Meirleir L, De Raeve L, Ramet J, Vandenplas Y. Acrodermatitis-like syndrome in organic aciduria. Pediatrics. $1994 ; 93: 537$. 